\title{
Spatial and Vertical Variations and Heavy Metal Enrichments in Irrigated Soils of the Syr Darya River Watershed, Aral Sea Basin, Kazakhstan
}

\author{
Long Ma 1,2,3®, Jilili Abuduwaili 1,2,3,* Z Zhassulan Smanov 1,2,3,4 , Yongxiao Ge ${ }^{1,2,3}$, \\ Kanat Samarkhanov ${ }^{1,2,3}\left(\mathbb{0}\right.$, Galymzhan Saparov ${ }^{4}$ and Gulnura Issanova ${ }^{5}$ \\ 1 State Key Laboratory of Desert and Oasis Ecology, Xinjiang Institute of Ecology and Geography, \\ Chinese Academy of Sciences, Urumqi 830011, China; malong@ms.xjb.ac.cn (L.M.); \\ zhassulan.smanov1307@gmail.com (Z.S.); geyx@ms.xjb.ac.cn (Y.G.); skgeo@mail.ru (K.S.) \\ 2 Research Center for Ecology and Environment of Central Asia, Chinese Academy of Sciences, \\ Urumqi 830011, China \\ 3 University of Chinese Academy of Sciences, Beijing 10049, China \\ 4 Kazakh Research Institute of Soil Science and Agrochemistry Named after U. U. Uspanov, \\ Almaty 050060, Kazakhstan; saparov.g@mail.ru \\ 5 Faculty of Geography and Environmental Sciences, Al-Farabi Kazakh National University, \\ Almaty 050040, Kazakhstan; gul_nur.777@mail.ru \\ * Correspondence: jilil@ms.xjb.ac.cn
}

Received: 17 October 2019; Accepted: 9 November 2019; Published: 11 November 2019

\begin{abstract}
In the Syr Darya River watershed, 225 samples from three different layers in 75 soil profiles were collected from irrigated areas in three different spatial regions (I: $n=29$; II: $n=17$; III: $n=29$ ), and the spatial and vertical variation characteristics of potentially toxic elements $(\mathrm{Cd}, \mathrm{Co}, \mathrm{Cu}, \mathrm{Ni}$, and $\mathrm{Zn})$ and a metallic element (Mn) were studied. The human health risks and enrichment factors were also evaluated in the Syr Darya River watershed of the Aral Sea Basin in Kazakhstan. There were significant differences in the contents of heavy metals in the different soil layers in the different sampling regions. Based on element variation similarity revealed by hierarchical cluster analysis, the elemental groupings were consistent in the different layers only in region I. For regions II and III, the clustered elemental groups were the same between surface layer A and B, but differed from those in the deep layer C. In sampling region I, the heavy metals in surface soils were significantly correlated with the ones in deep layers, reflecting that they were mainly affected by the elemental composition of parent materials. In region II, the significant correlations only existed for $\mathrm{Cu}, \mathrm{Mn}$, and $\mathrm{Zn}$ between the surface and deep layers. The similar phenomenon with significant correlation was also observed for heavy metals in sampling region III, except for Cd. Finally, enrichment factor was used to study the mobilization and enrichment of potentially toxic elements. The enrichment factors of $\mathrm{Zn}, \mathrm{Cu}$, and $\mathrm{Cd}$ in surface layer $\mathrm{A}$ that were greater than 1.5 accounted for $1.16 \%, 6.79 \%$, and $24.36 \%$ of sampling region I, respectively. In sampling region II, the enrichment factors of $\mathrm{Zn}, \mathrm{Cu}$, $\mathrm{Cd}$, and Co that were greater than 1.5 accounted for $0.03 \%, 4.76 \%, 0.54 \%$, and $9.03 \%$ of the total area, respectively. In sampling region III, only the enrichment factors of $\mathrm{Zn}, \mathrm{Cu}$, and $\mathrm{Cd}$ that exceeded 1.5 accounted for $0.24 \%, 4.90 \%$, and $6.89 \%$ of the total area, respectively. Although the contents of the heavy metals were not harmful to human health, the effects of human activities on the heavy metals in the irrigated soils revealed by enrichment factors have been shown in this study area.
\end{abstract}

Keywords: heavy metals; enrichment factor; human health risk; irrigated soils; Syr Darya River; Kazakhstan 


\section{Introduction}

Human environmental modifications have greatly increased over the past century, and human land use has altered the structure and functioning of ecosystems [1-3]. Soil quality is critical for human health, and it is not surprising that soil research has increased exponentially in recent decades $[4,5]$. The geochemical composition of soils is a direct indicator of soil quality and reflects not only the soil's natural condition but also the influences of human activities [6-8]. Soil heavy metals have many sources, including the parent material, atmospheric deposition, and various human activities such as generate suspended dust and sewage drainage, fertilizers, and irrigation water [9,10]. Soil pH [11,12], organic matter [13,14], soil texture [15] are the main factors controlling the distribution of heavy metals. A great deal of research has focused on land use $[16,17]$ and soil salinization in central Asia $[18,19]$, but there are no studies on the geochemical composition and levels of heavy metals in the soils in this area.

The Syr Darya River is the second largest river in the Aral Sea Basin; most of the research on this system has focused on the water source of the Syr Darya River [20,21], changes in the water volume of the Syr Darya River and its influencing factors [22-25], water resource countermeasures [26,27], and climate change effects [28-30]. The irrigated land in Kazakhstan is mainly distributed along the Syr Darya River [31] (Figure 1). On the one hand, the heavy metals in soils are directly related to public health and indirectly affect societal and economic development. However, previous studies have paid relatively less attention to variabilities in the heavy metals in the farmland soils in this region. On the other hand, disasters in the Aral Sea in central Asia have had a profound impact on the environment. The chemical substances in salt storms from the Aral Sea [32,33] are indirectly derived from the erosion of surface materials, and the heavy metals in salt storms have important impacts on the ecological environment [34]. The lack of research on the characteristics and distribution of heavy metals in farmland soils has a far-reaching influence on the sustainable development of agriculture in central Asia under the background of global change; indirectly, the study of the material sources of salt dust storms in the Aral Sea is affected, which is an important research gap regarding comprehensive environmental regulations of the Aral Sea.

The aims of this study were to answer the following scientific questions. What are the vertical and spatial distribution characteristics of the heavy metals in irrigated soils in the region of the Syr Darya River? Is there an inheritance relationship between the heavy metals in different soil layers in the soil profiles? Do farming activities by humans significantly change the content of heavy metals in the farmland soils?

\section{Materials and Methods}

\subsection{Sampling and Laboratory Analysis}

For the sampling region I, the bedrocks are mainly composed of mixed sedimentary rocks and a small number of unconsolidated sediments [35], and the soils in the study area are composed of Anthrosols and a small number of Calcisols from Harmonized World Soil Database (v 1.2) [36]. In this region, annual total precipitation was $340.1 \mathrm{~mm}$ (multi-year annual average from 1901-2018), and mean annual temperature of $15.1^{\circ} \mathrm{C}$ (multi-year monthly average from 1901-2018) [37]. For the sampling region II, the bedrocks are mainly composed of unconsolidated sediments and a small number of mixed sedimentary rocks [35], and the soils in the study area are composed of Gleysols and a small number of Solonchaks [36]. It is the typical temperate continental arid climate, with annual total precipitation of $128.7 \mathrm{~mm}$ (multi-year annual average from 1901-2018), and mean annual temperature of $9.8^{\circ} \mathrm{C}$ (multi-year monthly average from 1901-2018) [37]. The bedrocks in the sampling region III are same as the region II [35], and the soils in the study area are Calcisols [36]. It is the typical temperate continental arid climate, with annual total precipitation of $119.5 \mathrm{~mm}$ (multi-year annual average from 1901-2018), and mean annual temperature of $8.9^{\circ} \mathrm{C}$ (multi-year monthly average from 1901-2018) [37]. 
From three relatively independent irrigation regions (I, II, and III, Figure 1) along the Syr Darya River, 75 soil profiles were excavated to a depth of $100 \mathrm{~cm}$ (I: $n=29 ;$ II: $n=17$; III: $n=29$ ), and three soil samples were collected from three different layers in each profile $(0-20,21-50$, and 51-100 cm). In total, 225 soil samples were air-dried and sieved through a $2 \mathrm{~mm}$ sieve. Soil $\mathrm{pH}$ (pH electrode meter, PHS-3C, LeiCi Co. Ltd., Shanghai, China) was measured of deionized water suspension of 1:2.5 (w/v), electrical conductivity (EC; conductivity meter, DDS-307, LeiCi Co. Ltd., Shanghai, China) was determined in deionized water suspension of 1:5 (w/v) [38,39]. The contents of potentially toxic elements ( $\mathrm{Cd}, \mathrm{Co}, \mathrm{Cr}, \mathrm{Cu}, \mathrm{Ni}$, and $\mathrm{Zn})$ and a metallic element $(\mathrm{Mn})$ were analyzed with the strong acid $\left(\mathrm{HNO}_{3}-\mathrm{HClO}_{4}\right)$ pseudototal digestion method [40] and determined by inductively coupled plasma mass spectrometry (ICP-MS). The abovementioned analyses were performed at the Research Center for Ecology and Environment of Central Asia (Almaty).

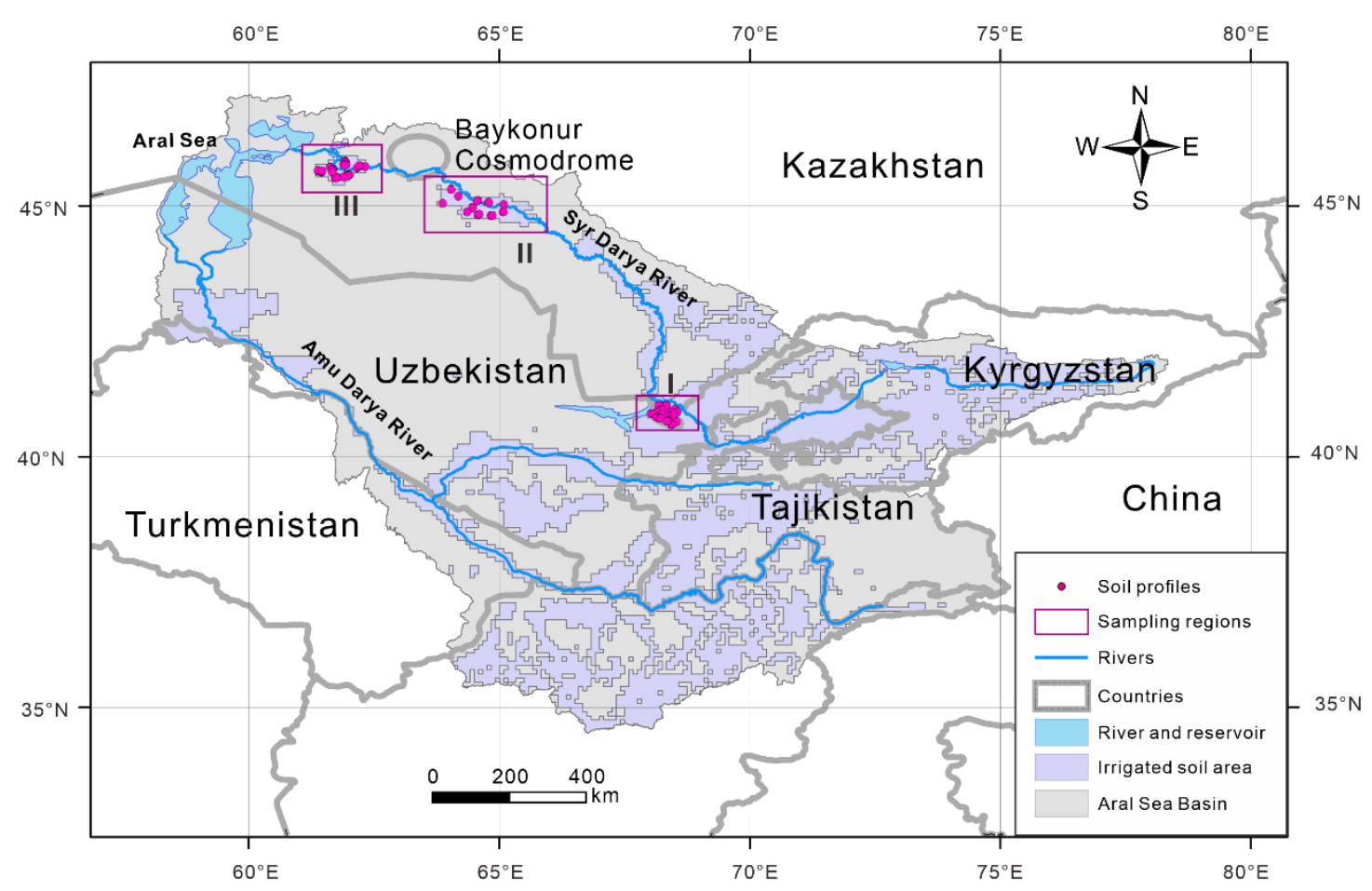

Figure 1. Locations of the study regions (I, II, and III) and distributions of the soil sampling profiles (I: $n=29$; II: $n=17$; III: $n=29$ ). The boundaries of the irrigation areas are from the literature [31]. The geographical coordinates of the soil profiles are shown in Table S1 in the supplementary file.

\subsection{Statistical Analysis}

Hierarchical cluster analysis (HCA) is the most commonly used environmental analysis method and reveals variable groups based on their similarities [41-45]. In this study, HCA was used to evaluate the differences and similarities of the heavy metals in different soil layers, and the grouping results were presented in a dendrogram [46]. Linear regression was used to study the relationship of the heavy metals in the different soil layers $[47,48]$.

\subsection{Enrichment Assessments}

The enrichment factor (EF) metric has been used to assess the enrichment extent of potentially toxic elements $(\mathrm{Cd}, \mathrm{Co}, \mathrm{Cr}, \mathrm{Cu}, \mathrm{Ni}$, and $\mathrm{Zn})$ in soils and can also be used to distinguish between anthropogenic sources and natural sources $[44,49,50]$. EF was calculated by dividing the ratio of the 
content of a potentially toxic element to its background content by the ratio of the content of a reference element to its background content [51]:

$$
\mathrm{EF}=\frac{\left(C_{i} / C_{\text {ref }}\right)_{\text {sample }}}{\left(B_{i} / B_{\text {ref }}\right)_{\text {background }}}
$$

where $C_{i}$ is the content of a potentially toxic element in the soil $(\mathrm{mg} / \mathrm{kg}) ; C_{\text {ref }}$ is the background content of the potentially toxic element $(\mathrm{mg} / \mathrm{kg}) ; B_{i}$ is the content of a reference element $(\mathrm{mg} / \mathrm{kg})$ within the same layer as $C_{i}$; and $B_{\text {ref }}$ is the background content of the reference element $(\mathrm{mg} / \mathrm{kg})$. In this study, a metallic element $(\mathrm{Mn})$ was used as the reference element because the concentration of $\mathrm{Mn}$ in the earth's crust is relatively high and more stable [52-55].

\subsection{Health Risk Assessment}

Human health risk assessments are widely used to evaluate the health risks of heavy metals in soils [55-57]. A noncarcinogenic hazard index was calculated for three exposure pathways (i): Ingestion, direct ingestion, and indirect ingestion via produce consumption; dermal contact; and inhalation, inhalation of resuspended soil particulates by nose or mouth [58]. For exposure pathway (i), noncarcinogenic hazards, such as the hazard quotient (HQi), were calculated with the rate of the corresponding reference dose for the exposure pathway (RfDi):

$$
\begin{gathered}
H Q_{i}=A D D_{i} / R f D_{i} \\
A D D_{\text {ing }}\left(m g \cdot \mathrm{kg}^{-1} \cdot d a y^{-1}\right)=C_{x} \times \frac{I n g R \times E x F \times E D}{B W \times A T} \times 10^{-6} \\
A D D_{\text {inh }}\left(\mathrm{mg} \cdot \mathrm{kg}^{-1} \cdot d a y^{-1}\right)=C_{x} \times \frac{\operatorname{InhR} \times E x F \times E D}{P E F \times B W \times A T} \\
A D D_{\text {derm }}\left(\mathrm{mg} \cdot \mathrm{kg}^{-1} \cdot \mathrm{day}^{-1}\right)=C_{x} \times \frac{S A \times S L \times A B S \times E x F \times E D}{B W \times A T} \times 10^{-6}
\end{gathered}
$$

where $A D D_{\text {ing }}$ is the average daily intake via ingestion; $A D D_{i n h}$ is the average daily intake via inhalation; $A D D_{\text {derm }}$ is the average daily intake via dermal absorption; $C_{x}$ is the potentially toxic element content $\left(\mathrm{mg} \mathrm{kg}^{-1}\right)$. In this study, the maximum values of potentially toxic elements in the surface layers were chosen as $C_{x} ; \operatorname{Ing} R$ is the ingestion rate $\left(200 \mathrm{mg}\right.$ day $\left.{ }^{-1}\right)$ [59]; $E x F$ is the exposure frequency (350 day year ${ }^{-1}$ ) [60]; ED is the exposure duration (30 a) [60]; $B W$ is body weight (70 kg) [60]; $A T$ is the exposure time $(A T=365 \times E D)$; InhR is the inhalation rate $\left(12.8 \mathrm{~m}^{3} \mathrm{day}^{-1}\right)$ [61]; $P E F$ is particle emission factor $\left(1.36 \times 10^{9} \mathrm{~m}^{3} \mathrm{~kg}^{-1}\right)$ [59]; $S A$ is the exposed skin area $\left(4350 \mathrm{~cm}^{2}\right)$ [61]; $S L$ is the skin adherence factor $\left(0.2 \mathrm{mg} \mathrm{cm}^{-2} \mathrm{day}^{-1}\right)$; and $A B S$ is a dimensionless dermal absorption factor $(A B S=0.001$; for As, $A B S=0.03[59])$.

The hazard index (HI) was calculated as follows:

$$
H I=\sum_{i=1}^{3} H Q_{i}
$$

If $\mathrm{HI}<1$ or $\mathrm{HQ}<1$, there are no noncarcinogenic risks; otherwise, the state of $\mathrm{HI}>1$ or $\mathrm{HQ}>1$ inferred that noncarcinogenic effects exist [62]. 


\section{Results and Discussion}

\subsection{Statistical Characteristics of the Soil Geochemical Indicators}

The $\mathrm{pH}, \mathrm{EC}$, and contents of heavy metals of the soils differed in the three sampling regions. There were also great differences in the $\mathrm{pH}, \mathrm{EC}$, and contents of heavy metals in the different soil layers in a single sampling region (Figure 2 and Table 22 in the supplementary file).
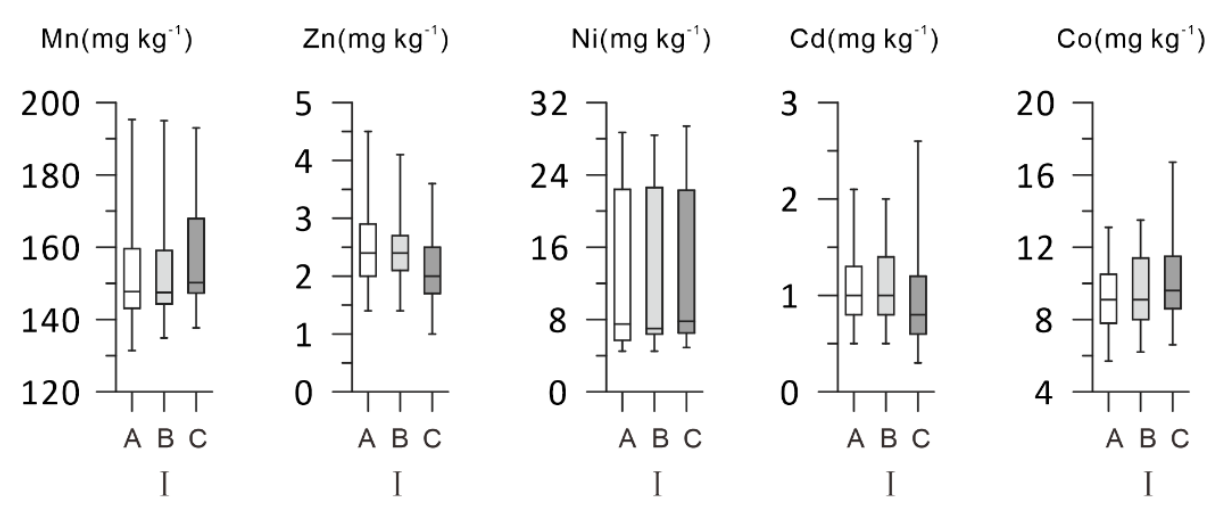

$\mathrm{Cu}\left(\mathrm{mg} \mathrm{kg}^{-1}\right)$
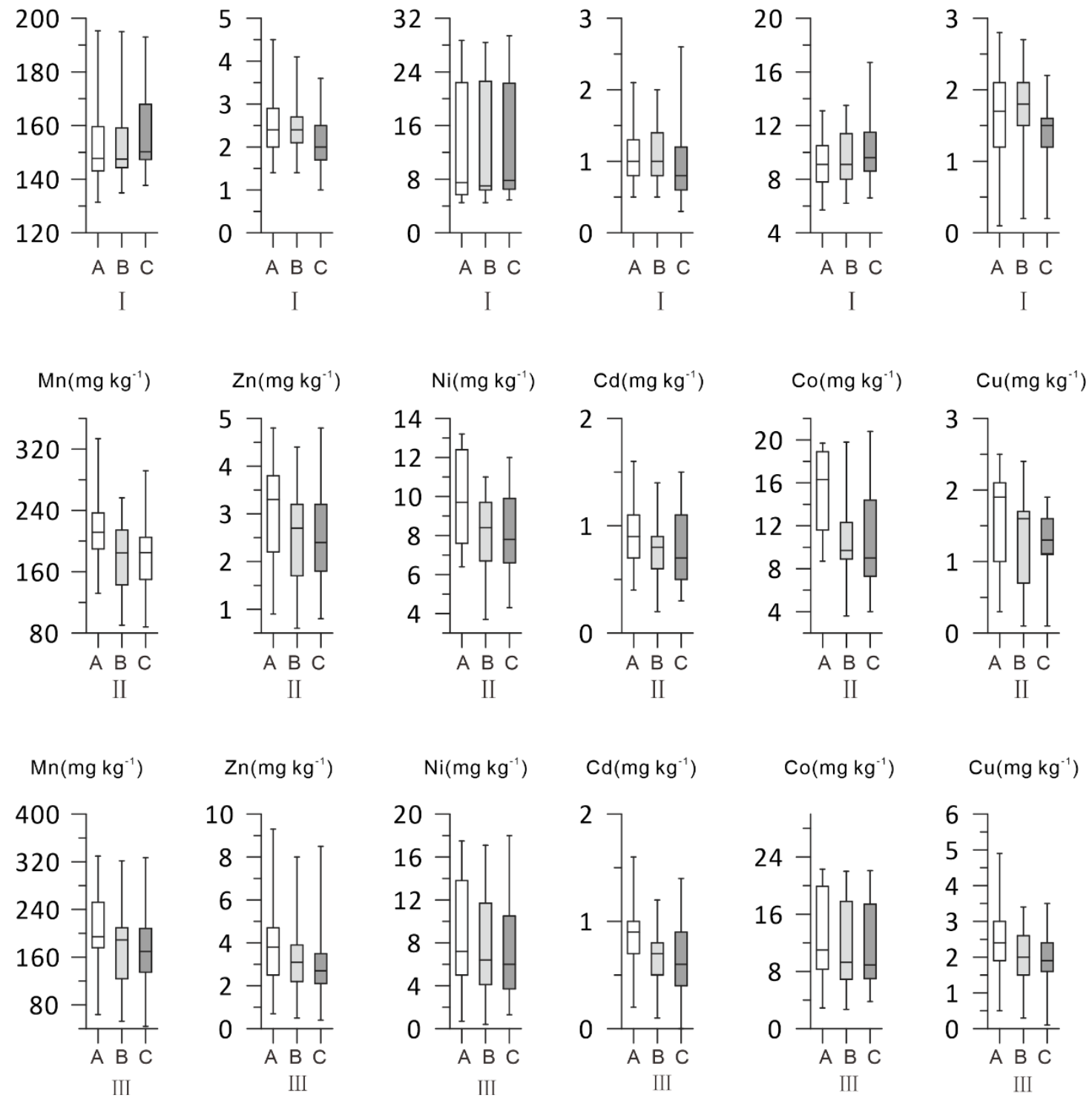

Figure 2. The vertical box plots display the minimum, maximum, median, lower quartile, and upper quartile data of the heavy metals in the three sampling regions (I: $n=29$; II: $n=17$; III: $n=29$ ). A: The 0-20 cm soil layer; B: The $21-50 \mathrm{~cm}$ soil layer; and C: The $51-100 \mathrm{~cm}$ soil layer.

In sampling region I, the surface soil $(0-20 \mathrm{~cm}) \mathrm{pH}$ ranged from 7.5 to 8.4 , with an average of 8.0. The EC ranged from $62.2-1222 \mu \mathrm{S} \mathrm{cm}{ }^{-1}$, with an average of $414.2 \mu \mathrm{S} \mathrm{cm}{ }^{-1}$. The average contents of $\mathrm{Zn}$, $\mathrm{Cu}, \mathrm{Cd}, \mathrm{Ni}, \mathrm{Co}$, and $\mathrm{Mn}$ were $2.5,1.7,1.1,13.6,9.4$, and $153.4 \mathrm{mg} \mathrm{kg}^{-1}$, respectively. The $\mathrm{pH}$ values of the soils in the middle layer $(21-50 \mathrm{~cm})$ ranged from $7.2-8.5$, with an average of 8.0. The EC ranged from 104.4-1369 $\mu \mathrm{S} \mathrm{cm}^{-1}$, with an average of $476.9 \mu \mathrm{sm}^{-1}$. The average contents of $\mathrm{Zn}, \mathrm{Cu}, \mathrm{Cd}, \mathrm{Ni}$, $\mathrm{Co}$, and Mn were 2.5, 1.7, 1.1, 14.1, 9.6, and $154.2 \mathrm{mg} \mathrm{kg}^{-1}$, respectively. The $\mathrm{pH}$ values of the soils 
in the deepest layer $(51-100 \mathrm{~cm})$ ranged from 7.4 to 8.8 , with an average of 8.0. The EC ranged from 61.4-1417 $\mu \mathrm{S} \mathrm{cm}^{-1}$, with an average of $451.3 \mu \mathrm{S} \mathrm{cm}^{-1}$. The average contents of $\mathrm{Zn}, \mathrm{Cu}, \mathrm{Cd}, \mathrm{Ni}, \mathrm{Co}$, and Mn were 2.1, 1.4, 0.9, 14.1, 10.0, and $157.1 \mathrm{mg} \mathrm{kg}^{-1}$, respectively.

For sampling region II, the surface soil $(0-20 \mathrm{~cm}) \mathrm{pH}$ ranged from 7.6 to 8.5 , with an average of 8.0. The EC ranged from $215-2660 \mu \mathrm{S} \mathrm{cm}{ }^{-1}$, with an average of $1231.4 \mu \mathrm{S} \mathrm{cm}^{-1}$. The average contents of $\mathrm{Zn}, \mathrm{Cu}, \mathrm{Cd}, \mathrm{Ni}, \mathrm{Co}$, and $\mathrm{Mn}$ were 3.1, 1.6, $0.9,9.9,15.0$, and $216.4 \mathrm{mg} \mathrm{kg}^{-1}$, respectively. The $\mathrm{pH}$ values of the soils in the middle layer $(21-50 \mathrm{~cm})$ ranged from 7.7-8.5, with an average of 8.1. The EC ranged from $179.5-2330 \mu \mathrm{S} \mathrm{cm}{ }^{-1}$, with an average of $845.4 \mu \mathrm{S} \mathrm{cm}^{-1}$. The average contents of $\mathrm{Zn}, \mathrm{Cu}, \mathrm{Cd}, \mathrm{Ni}$, $\mathrm{Co}$, and Mn were 2.5, 1.2, $0.8,8.2,10.6$, and $174.3 \mathrm{mg} \mathrm{kg}^{-1}$, respectively. The $\mathrm{pH}$ values of the soils in the deepest layer $(51-100 \mathrm{~cm}$ ) ranged from 7.8 to 8.6 , with an average of 8.1. The EC ranged from $148.8-1387 \mu \mathrm{S} \mathrm{cm}^{-1}$, with an average of $570.8 \mu \mathrm{S} \mathrm{cm}^{-1}$. The average contents of $\mathrm{Zn}, \mathrm{Cu}, \mathrm{Cd}, \mathrm{Ni}, \mathrm{Co}$, and $\mathrm{Mn}$ were $2.5,1.2,0.8,8.2,11.1$, and $179.0 \mathrm{mg} \mathrm{kg}^{-1}$, respectively.

For sampling region III, the surface soil $(0-20 \mathrm{~cm}) \mathrm{pH}$ ranged from 7.3 to 8.9 , with an average of 8.1. The EC ranged from $149.4-5020 \mu \mathrm{S} \mathrm{cm}^{-1}$, with an average of $1547.5 \mu \mathrm{S} \mathrm{cm}^{-1}$. The average contents of $\mathrm{Zn}, \mathrm{Cu}, \mathrm{Cd}, \mathrm{Ni}, \mathrm{Co}$, and $\mathrm{Mn}$ were $4.0,2.4,0.8,8.8,13.3$, and $199.2 \mathrm{mg} \mathrm{kg}^{-1}$, respectively. The $\mathrm{pH}$ values of the soils in the middle layer $(21-50 \mathrm{~cm}$ ) ranged from 7.2-8.7, with an average of 8.2. The EC ranged from $165-3540 \mu \mathrm{S} \mathrm{cm}^{-1}$, with an average of $1007 \mu \mathrm{S} \mathrm{cm}^{-1}$. The average contents of $\mathrm{Zn}, \mathrm{Cu}, \mathrm{Cd}$, $\mathrm{Ni}, \mathrm{Co}$, and $\mathrm{Mn}$ were 3.4, 2.0, 0.6, 7.7, 11.8, and $173.0 \mathrm{mg} \mathrm{kg}^{-1}$, respectively. The $\mathrm{pH}$ values of the soils in the deepest layer $(51-100 \mathrm{~cm}$ ) ranged from 7.9 to 8.8 , with an average of 8.3. The EC ranged from 134-3270 $\mu \mathrm{S} \mathrm{cm}^{-1}$, with an average of $937.2 \mu \mathrm{S} \mathrm{cm}{ }^{-1}$. The average contents of $\mathrm{Zn}, \mathrm{Cu}, \mathrm{Cd}, \mathrm{Ni}, \mathrm{Co}$, and Mn were 3.2, 2.0, 0.6, 7.5, 11.8, and $170.9 \mathrm{mg} \mathrm{kg}^{-1}$, respectively.

As can also be seen from Figure 2 and Table $\mathrm{S} 2$ in supplementary file, the content of $\mathrm{Cu}, \mathrm{Cd}$, and Co in sampling region III is higher than that in sampling regions I and II. According to the published studies [63], the content of $\mathrm{Cu}, \mathrm{Cd}$, and Co in water samples from the lower reaches of the Syr Darya River is also higher than that in the upper reaches. This may reflect that some parts of the heavy metals in the soils of the sampling region III may be derived from the transport of heavy metals from the upper reaches of the Syr Darya River.

\subsection{Spatial and Vertical Variation in the Surface Soil Elements and Its Influencing Factors}

HCA was always used to analyze the interrelationships among the environmental variables [64-66]. The horizontal axis reflected the degree of the similarities among the heavy metals (Figure 3). Regarding the spatial variation, the similarity relationships among the elements in the three sampling regions differed significantly, which reflected significant differences in the soil formation environments (Figure 3). $\mathrm{Cu}$ and $\mathrm{Mn}$ in the surface layers of the first sampling region had similar characteristics, and $\mathrm{Ni}, \mathrm{Co}, \mathrm{Cd}$, and $\mathrm{Zn}$ had similar variations. $\mathrm{Co}$ and $\mathrm{Ni}$ in the surface soils of the second region had similar variation characteristics, and $\mathrm{Zn}, \mathrm{Cu}, \mathrm{Cd}$, and $\mathrm{Mn}$ had similar variation characteristics. In the surface soil of the third sampling region, $\mathrm{Ni}, \mathrm{Co}$, and $\mathrm{Mn}$ were similar, $\mathrm{Cu}$ and $\mathrm{Zn}$ were similar, and $\mathrm{Cd}$ was far from the other elements. Vertically, compared with the first layer A and the second layer $\mathrm{B}$, the affinity distances of the three elements of $\mathrm{Cd}, \mathrm{Ni}$, and $\mathrm{Co}$ changed in the third layer $\mathrm{C}$ in the first sampling region I. For sampling region II, $\mathrm{Co}$ and $\mathrm{Ni}$ in the surface soils had similar variation characteristics in the three soil layers of $\mathrm{A}, \mathrm{B}$, and $\mathrm{C}$, and $\mathrm{Zn}, \mathrm{Cu}, \mathrm{Cd}$, and $\mathrm{Mn}$ had similar variation characteristics. The similarity characteristics of the heavy metals in the sampling region III changed obviously. Specifically, the surface layer and middle layer of the second and third sampling regions were basically the same, i.e., $\mathrm{Ni}, \mathrm{Co}$, and $\mathrm{Mn}$ had the close similarity, however, $\mathrm{Ni}, \mathrm{Co}, \mathrm{Cu}$, and $\mathrm{Mn}$ were significantly clustered in the deep layer $\mathrm{C}$. 

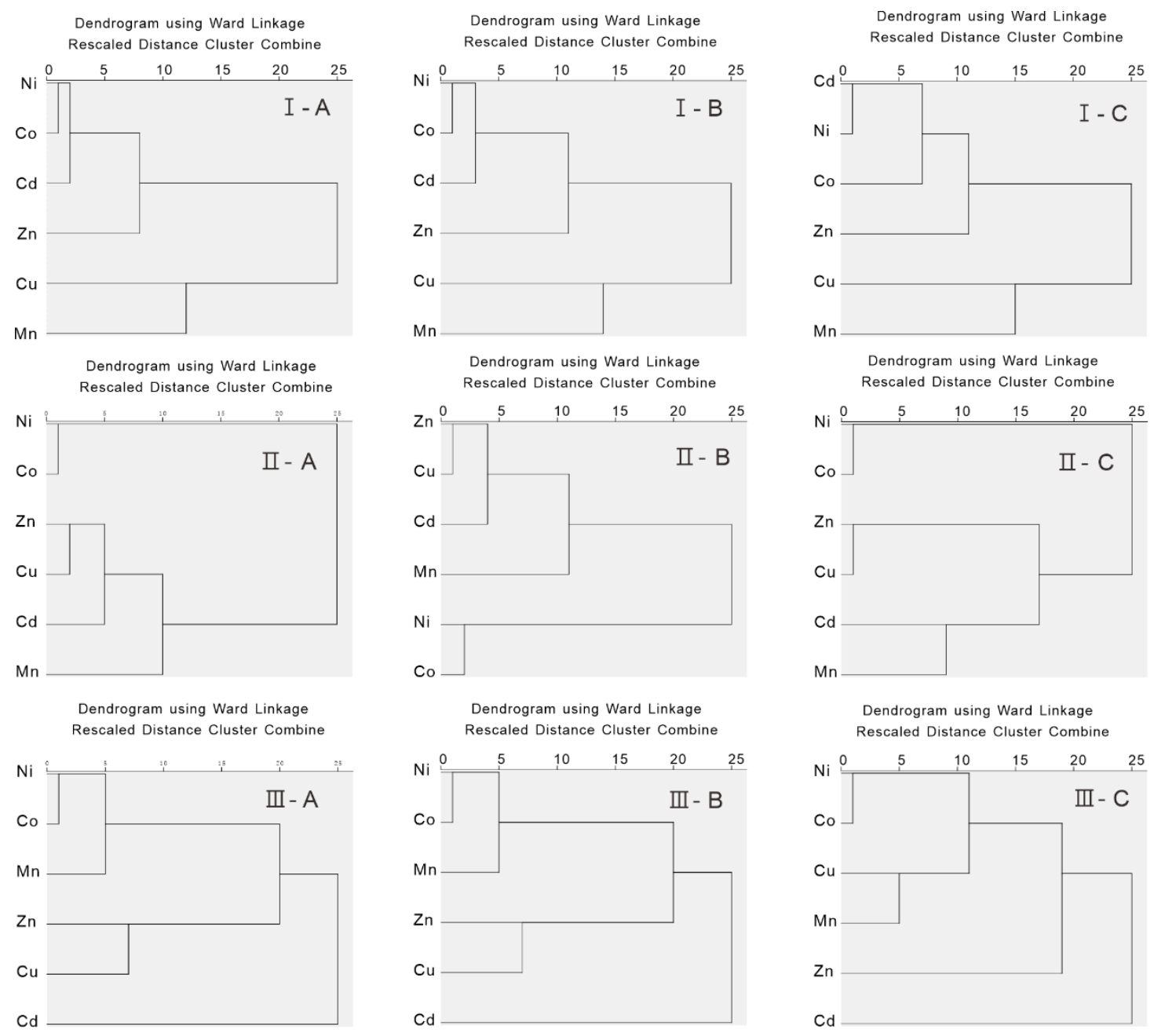

Figure 3. Of the cluster analysis data of the heavy metals in the three sampling regions (I: $n=29$; II: $n=17$; III: $n=29)$. A: The $0-20 \mathrm{~cm}$ soil layer; B: The $21-50 \mathrm{~cm}$ soil layer; and C: The $51-100 \mathrm{~cm}$ soil layer.

In the first sampling region I, the soil heavy metal elements were significantly correlated (Figure S1 in the supplementary file), reflecting that the heavy metals in the soil were mainly affected by the elemental composition of parent materials from which they are derived $[9,67]$. The coefficient of determination $\left(R^{2}\right)$ values of the linear regression equations between the contents of $\mathrm{Cd}, \mathrm{Co}, \mathrm{Cu}, \mathrm{Mn}$, $\mathrm{Ni}$, and $\mathrm{Zn}$ in the surface soil and the corresponding heavy metals in the middle soil were $0.79,0.91$, $0.82,0.92,0.99$, and 0.83 , respectively. The coefficient of determination $\left(R^{2}\right)$ between the contents of $C d$, $\mathrm{Co}, \mathrm{Cu}, \mathrm{Mn}, \mathrm{Ni}$, and $\mathrm{Zn}$ in the middle layer and the same heavy metal in the deep layers were 0.80 , $0.82,0.84,0.89,0.98$, and 0.82 , respectively. The coefficient of determination $\left(R^{2}\right)$ between the contents of $\mathrm{Cd}, \mathrm{Co}, \mathrm{Cu}, \mathrm{Mn}, \mathrm{Ni}$, and $\mathrm{Zn}$ in the surface soils and the same heavy metal in the deep layers were $0.69,0.69,0.73,0.93,0.98$, and 0.63 , respectively.

In sampling region II, the $\mathrm{R}^{2}$ values of the linear regression equations for the potentially toxic elements $(\mathrm{Cu}, \mathrm{Mn}$, and $\mathrm{Zn})$ among the three different soil layers were greater than 0.5 (Figure $\mathrm{S} 2$ in the supplementary file). For two elements, $\mathrm{Cd}$ and $\mathrm{Ni}$, although the $\mathrm{R}^{2}$ values of the surface and middle linear regression equations were 0.58 and 0.68 , respectively, the $R^{2}$ values of the linear regression equations between the middle and deep layers were only 0.29 and 0.12 , respectively. There was no obvious linear relationship among the three layers for Co. This finding may indicate that the heavy metal elements in the upper and middle soils have been significantly affected by human activities. 
In sampling region III, the soil heavy metal elements in the surface layers were significantly correlated with those in the middle layers; however, the $\mathrm{R}^{2}$ value of the linear regression equation for $\mathrm{Cd}$ between the contents in the middle layers and deep layer was 0.38 , and the $\mathrm{R}^{2}$ the linear regression equation between the contents in the deep layers and top one was only 0.25 (Figure S3 in the supplementary file). Changes in the environmental factors in the process of soil formation in the late stage led to the composition of heavy metals in the upper and middle soil layers, which led to the deviation from the linear regression line.

\subsection{Human Risk Assessment and Enrichment of Potentially Toxic Elements in the Surface Soils}

From a global perspective, heavy metal pollution in soil caused by human activities has become increasingly serious $[68,69]$. According to existing studies in central Asia (e.g., the Lake Issyk-kul Basin [70] and the suburban region of Bishkek [71]), although the human health risk is low, it is affected by human activity. As shown in this paper, although the content of potentially toxic elements was not harmful to human health (Table 1, the thresholds of $\mathrm{Zn}, \mathrm{Cu}, \mathrm{Cd}, \mathrm{Ni}$, Co for $\mathrm{HI}=1$ were $107 \times 10^{3}, 14.4 \times 10^{3}, 254,7.2 \times 10^{3}$, and $6.2 \times 10^{3} \mathrm{mg} \mathrm{kg}^{-1}$, respectively), it is also necessary to study the enrichment of potentially toxic elements caused by human activities.

Table 1. Human health risk assessment of the potentially toxic elements in the surface soils of the Syr Darya River Watershed.

\begin{tabular}{|c|c|c|c|c|c|c|}
\hline $\begin{array}{l}\text { Sampling } \\
\text { Region }\end{array}$ & $\begin{array}{c}\text { Potentially } \\
\text { Toxic Elements }\end{array}$ & $\begin{array}{c}\text { Maximum } \\
\text { Value }\left(\mathrm{mg} \mathrm{kg}^{-1}\right)^{a}\end{array}$ & $H Q_{\text {ing }}{ }^{b}$ & $H Q_{\text {inh }}{ }^{c}$ & $H Q_{\text {dermal }}{ }^{d}$ & $\mathrm{HI}^{\mathrm{e}}=\Sigma \mathrm{HQ}_{\mathrm{i}}$ \\
\hline \multirow{5}{*}{ I } & $\mathrm{Zn}$ & 4.5 & $4.1 \times 10^{-5}$ & $1.9 \times 10^{-9}$ & $8.9 \times 10^{-7}$ & $4.2 \times 10^{-5}$ \\
\hline & $\mathrm{Cu}$ & 2.8 & $1.9 \times 10^{-4}$ & $9.0 \times 10^{-9}$ & $2.8 \times 10^{-6}$ & $2.0 \times 10^{-4}$ \\
\hline & $\mathrm{Cd}$ & 2.1 & $5.8 \times 10^{-3}$ & $2.7 \times 10^{-7}$ & $2.5 \times 10^{-3}$ & $8.3 \times 10^{-3}$ \\
\hline & $\mathrm{Ni}$ & 28.7 & $3.9 \times 10^{-3}$ & $1.9 \times 10^{-7}$ & $6.3 \times 10^{-5}$ & $4.0 \times 10^{-3}$ \\
\hline & Co & 13.1 & $1.8 \times 10^{-3}$ & $3.0 \times 10^{-4}$ & $9.8 \times 10^{-6}$ & $2.1 \times 10^{-3}$ \\
\hline \multirow{5}{*}{ II } & $\mathrm{Zn}$ & 4.8 & $4.4 \times 10^{-5}$ & $2.1 \times 10^{-9}$ & $9.5 \times 10^{-7}$ & $4.5 \times 10^{-5}$ \\
\hline & $\mathrm{Cu}$ & 2.5 & $1.7 \times 10^{-4}$ & $8.1 \times 10^{-9}$ & $2.5 \times 10^{-6}$ & $1.7 \times 10^{-4}$ \\
\hline & $\mathrm{Cd}$ & 1.6 & $4.4 \times 10^{-3}$ & $2.1 \times 10^{-7}$ & $1.9 \times 10^{-3}$ & $6.3 \times 10^{-3}$ \\
\hline & $\mathrm{Ni}$ & 13.2 & $1.8 \times 10^{-3}$ & $8.5 \times 10^{-8}$ & $2.9 \times 10^{-5}$ & $1.8 \times 10^{-3}$ \\
\hline & Co & 19.7 & $2.7 \times 10^{-3}$ & $4.5 \times 10^{-4}$ & $1.5 \times 10^{-5}$ & $3.2 \times 10^{-3}$ \\
\hline \multirow{5}{*}{ III } & $\mathrm{Zn}$ & 9.3 & $8.5 \times 10^{-5}$ & $4.0 \times 10^{-9}$ & $1.9 \times 10^{-6}$ & $8.7 \times 10^{-5}$ \\
\hline & $\mathrm{Cu}$ & 4.9 & $3.4 \times 10^{-4}$ & $1.6 \times 10^{-8}$ & $4.9 \times 10^{-6}$ & $3.4 \times 10^{-4}$ \\
\hline & $\mathrm{Cd}$ & 1.6 & $4.4 \times 10^{-3}$ & $2.1 \times 10^{-7}$ & $1.9 \times 10^{-3}$ & $6.3 \times 10^{-3}$ \\
\hline & $\mathrm{Ni}$ & 17.5 & $2.4 \times 10^{-3}$ & $1.1 \times 10^{-7}$ & $3.9 \times 10^{-5}$ & $2.4 \times 10^{-3}$ \\
\hline & $\mathrm{Co}$ & 22.3 & $3.1 \times 10^{-3}$ & $5.1 \times 10^{-4}$ & $1.7 \times 10^{-5}$ & $3.6 \times 10^{-3}$ \\
\hline
\end{tabular}

a The maximum values of potentially toxic elements in the surface layers were chosen as $C_{x}$ in the formula (3), (4), and (5). ${ }^{b}$ The hazard quotient (HQ) via ingestion. ${ }^{c}$ The hazard quotient (HQ) via inhalation. ${ }^{d}$ The hazard quotient

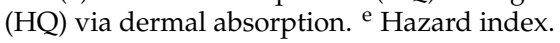

In sampling region I, based on the statistical characteristics, the $\mathrm{EFs}$ of $\mathrm{Zn}, \mathrm{Cu}$, and $\mathrm{Cd}$ exceeding 1.5 accounted for $10.3 \%, 10.3 \%$, and $34.5 \%$ of the total 29 soil profiles, respectively (Figure 4). Spatial variation in the EF of potentially toxic elements can be interpolated by inverse distance weighting [72]. According to the spatial distribution of the EFs of the potentially toxic elements, the EFs of $\mathrm{Zn}$ that were higher than one accounted for $97.62 \%$ of the total area, those exceeding 1.5 accounted for $1.16 \%$ of the total area, and there were no areas with EFs greater than two. The distribution areas of $\mathrm{Cu}$ and $\mathrm{Cd}$ with EFs greater than one accounted for $96.64 \%$ and $93.61 \%$ of the total area, the distribution areas greater than 1.5 accounted for $6.79 \%$ and $24.36 \%$ of the total area, and the distribution areas greater than two accounted for $1.15 \%$ and $0.51 \%$ of the total area, respectively. From the distribution maps of the EFs of $\mathrm{Ni}$ and $\mathrm{Co}$, EFs between 1.0 and 1.5 accounted for $26.29 \%$ and $0.36 \%$ of the total area, respectively, and there were no areas where the EF exceeded 1.5. 

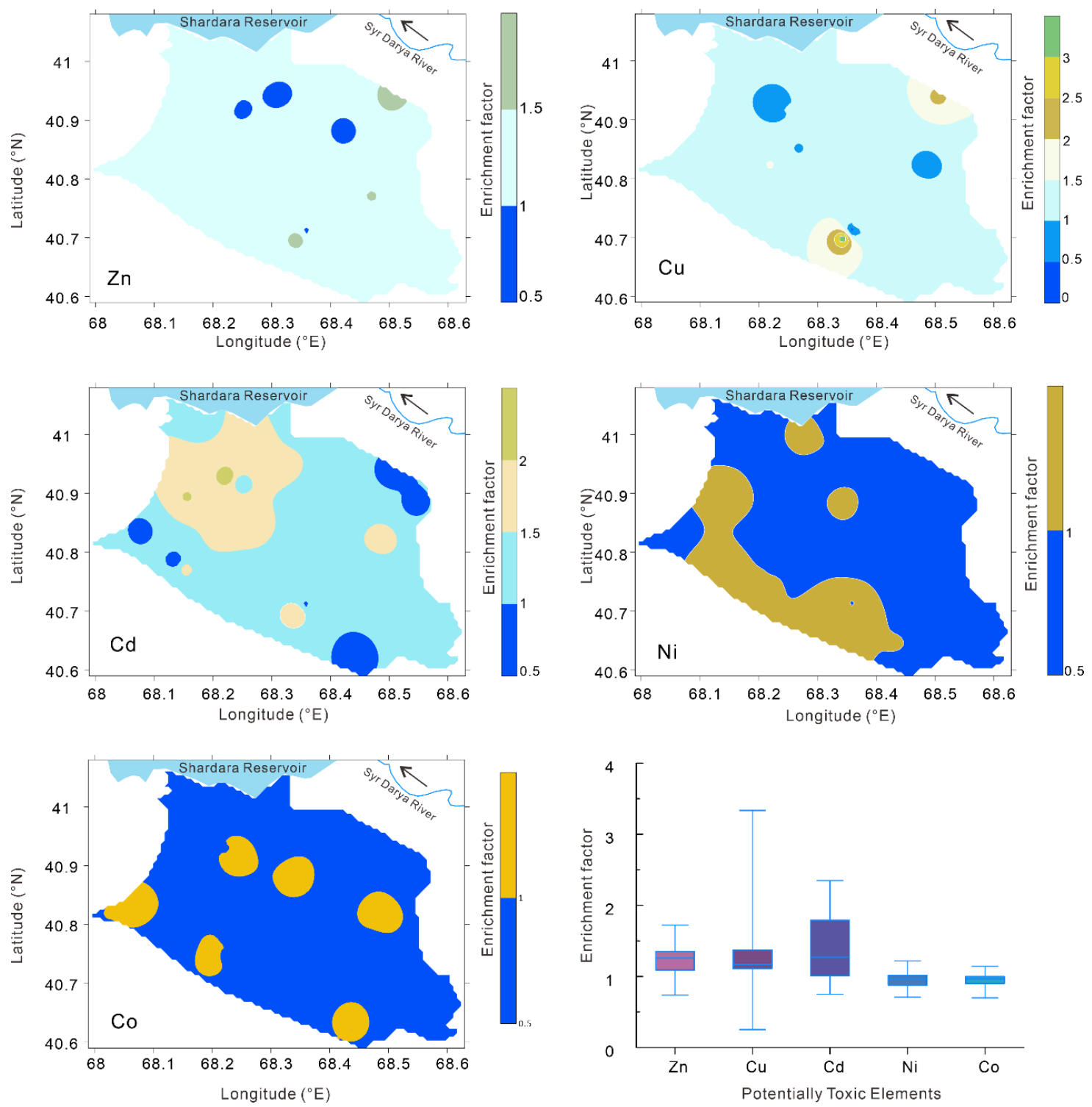

Figure 4. Basic statistical chart and spatial distribution maps of the enrichment coefficients of the potentially toxic elements in sampling region I.

In sampling region II, based on the statistical characteristics, the EFs of $\mathrm{Zn}, \mathrm{Cu}, \mathrm{Cd}$, and $\mathrm{Co}$ exceeding 1.5 accounted for $5.9 \%, 5.9 \%, 11.8 \%$, and $23.6 \%$ of the total 17 soil profiles, respectively (Figure 5). There was no EF of $\mathrm{Ni}$ in the soil exceeding 1.5. Moreover, the areas of $\mathrm{Zn}$ and $\mathrm{Cd}$ in the soil with EFs greater than 1.5 accounted for only $0.03 \%$ and $0.54 \%$ of the total area, respectively. For the potentially toxic elements $\mathrm{Cu}$ and Co, EFs greater than 1.5 accounted for $4.76 \%$ and $9.03 \%$ of the total area, respectively. 

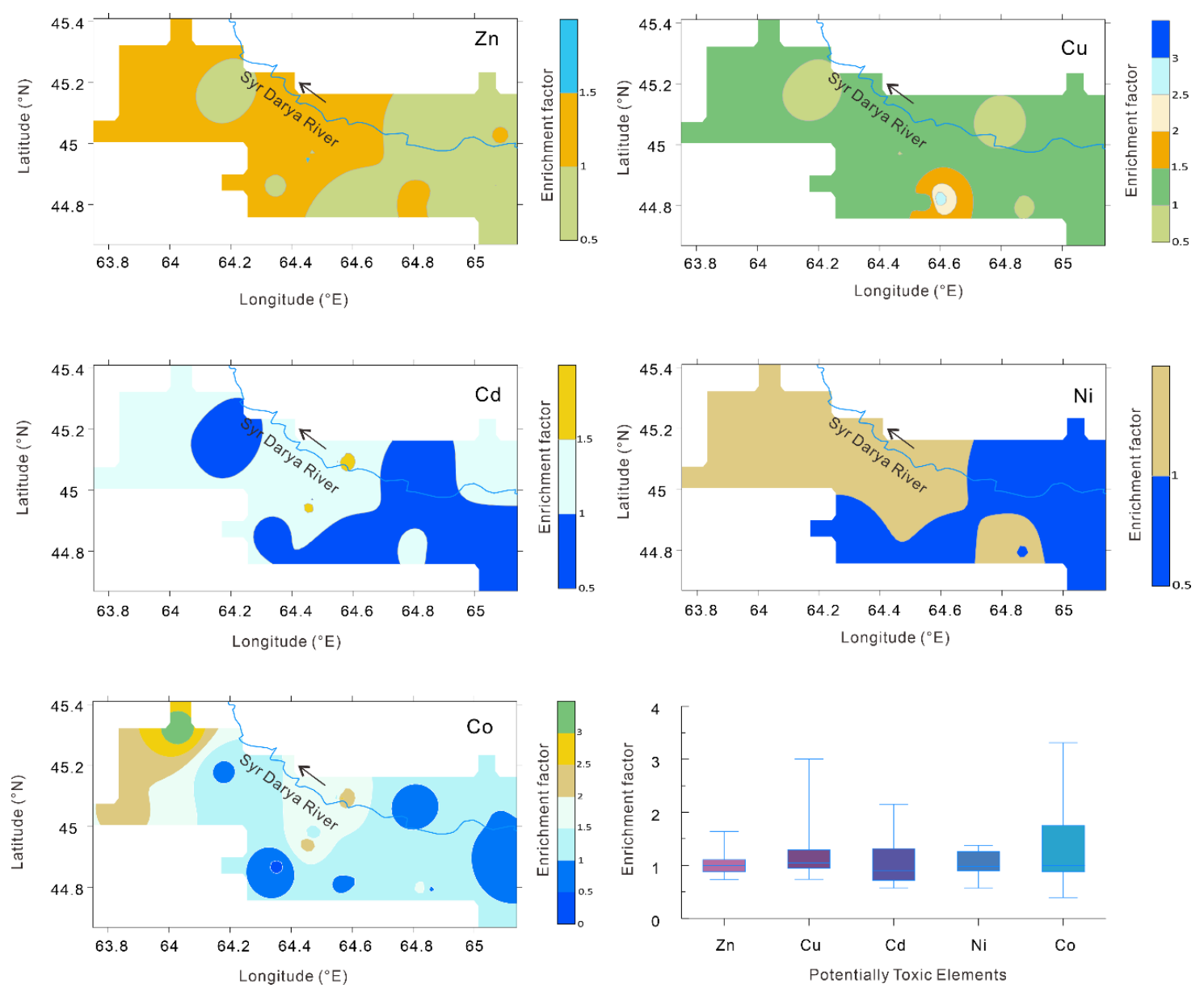

Figure 5. Basic statistical chart and spatial distribution maps of the enrichment coefficients of the potentially toxic elements in sampling region II.

In sampling region III, based on the statistical characteristics, the EFs of $\mathrm{Zn}, \mathrm{Cu}, \mathrm{Cd}$, and Co exceeding 1.5 accounted for $10.3 \%, 6.9 \%, 27.6 \%$ and $3.4 \%$ of the total 29 soil profiles, respectively (Figure 6). There were no EFs of $\mathrm{Ni}$ and $\mathrm{Co}$ in the soil exceeding 1.5. The area of $\mathrm{Zn}$ in the soil with an EF greater than 1.5 accounted for only $0.24 \%$ of the total area. For the potentially toxic elements $\mathrm{Cu}$ and Cd, EFs greater than 1.5 accounted for $4.9 \%$ and $6.89 \%$ of the total area, respectively.

An EF value close to one indicates a natural source, a value less than one indicates the possible mobilization/depletion of a metal [49,73], and an EF value greater than one indicates that the element is affected by a human factor [49,74]. In theory, a heavy metal with an EF greater than one suggests that the heavy metal is mainly influenced by human activities $[49,74-76]$. However, there have been a number of studies suggesting that an EF lower than 1.5 reflects that a metal is mainly from crustal materials, whereas an EF value $>1.5$ indicates non-natural weathering processes [77-79]. Combining the analysis in the previous section of this paper and the distribution of EFs in the region, it is more practical to use $\mathrm{EF}=1.5$ as a threshold for whether human activities affect heavy metal pollution in this region. Although the contents of the potentially toxic elements were not harmful to human health, the effects of human activities on the potentially toxic elements in irrigated soils revealed by EFs have been shown in this study area, which has resulted in a high degree of public concern. 

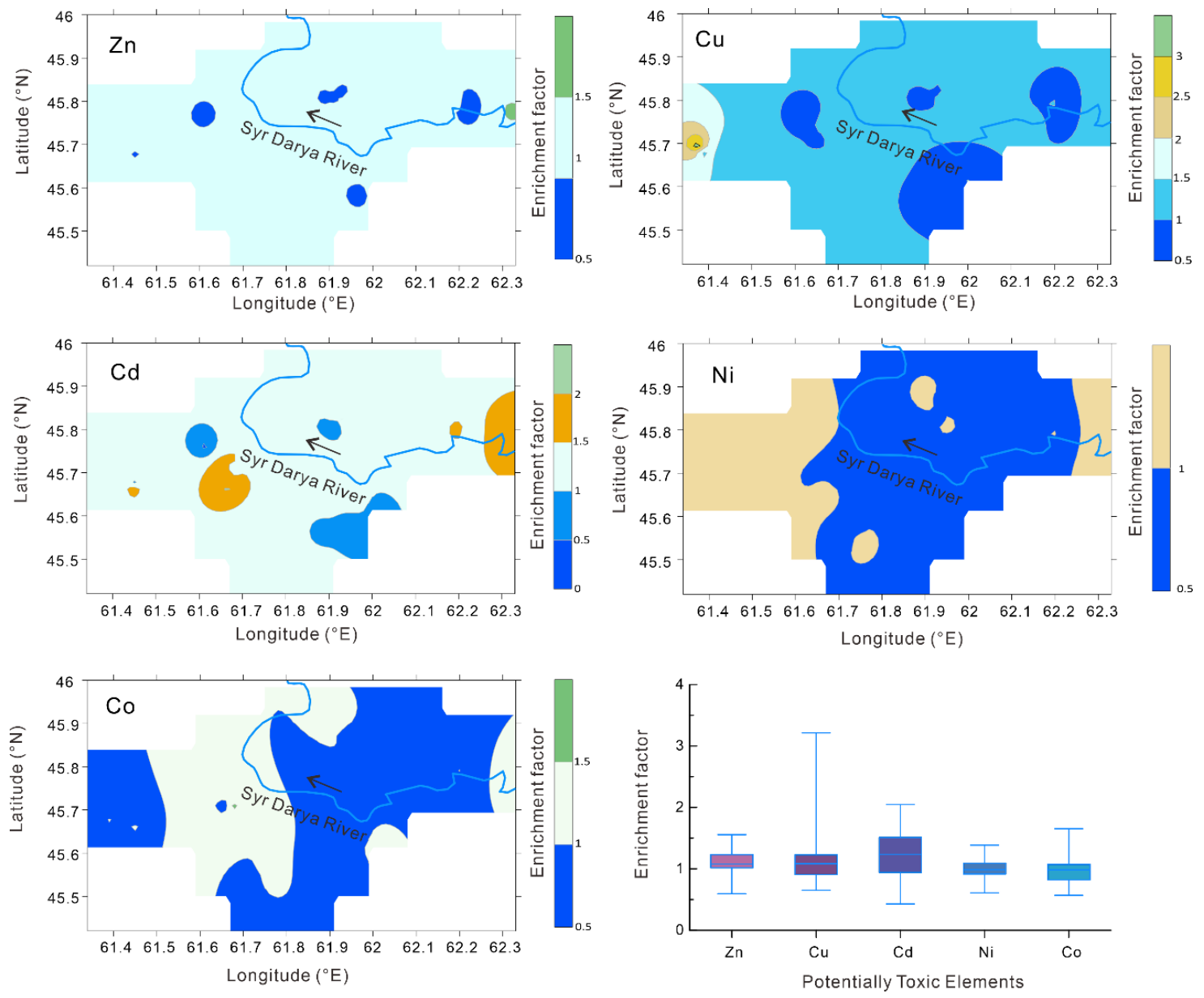

Figure 6. Basic statistical chart and spatial distribution maps of the enrichment coefficients of the potentially toxic elements in sampling region III.

\section{Conclusions}

By analyzing the heavy metals in the soil profiles in different irrigation areas of the Syr Darya River Basin, the spatial and vertical variation characteristics of heavy metals were determined, and the harm and enrichment of heavy metals to human health were evaluated. The conclusions are as follows.

(1) Environmental differences led to significant spatial differences in the similarities of the heavy metal elements in the soil. Based on element variation similarity revealed by HCA, the elemental groupings were consistent in the different layers only in region I. For regions II and III, the elemental groups in the surface soil layer and middle layer were basically the same but differed from those in the deep layer.

(2) In the first sampling region I, the heavy metals in surface soils were significantly correlated with the ones in deep layers, reflecting that they were mainly affected by the composition of parent materials. In the sampling region II, only $\mathrm{Cu}, \mathrm{Mn}$, and $\mathrm{Zn}$ showed significant correlations between the surface and deep layers. The similar phenomenon with significant correlation also existed heavy metals in the sampling region III, except for Cd.

(3) The contents of potentially toxic elements were not harmful to human health. It is more practical to use $\mathrm{EF}=1.5$ as the threshold for determining whether human activities affect heavy metal pollution in this region. The EFs of $\mathrm{Zn}, \mathrm{Cu}$, and $\mathrm{Cd}$ that were greater than 1.5 accounted for $1.16 \%$, $6.79 \%$, and $24.36 \%$ of sampling region I, respectively. In sampling region II, the EFs of $\mathrm{Zn}, \mathrm{Cu}, \mathrm{Cd}$, and Co that were greater than 1.5 accounted for $0.03 \%, 4.76 \%, 0.54 \%$, and $9.03 \%$ of the total area, 
respectively. In sampling region III, only the EFs of $\mathrm{Zn}, \mathrm{Cu}$ and $\mathrm{Cd}$ that exceeded 1.5 accounted for $0.24 \%, 4.90 \%$, and $6.89 \%$ of the total area, respectively.

Supplementary Materials: The following are available online at http://www.mdpi.com/1660-4601/16/22/4398/s1. Figure S1: Linear regressions for potentially toxic elements among three different layers in sampling region (I: $n=29$ ), A: The $0-20 \mathrm{~cm}$ soil layer; B: The $21-50 \mathrm{~cm}$ soil layer; and C: The $51-100 \mathrm{~cm}$ soil layer. Figure S2: Linear regressions for potentially toxic elements among three different layers in sampling region (II: $n=17$ ), A: The $0-20 \mathrm{~cm}$ soil layer; B: The $21-50 \mathrm{~cm}$ soil layer; and C: The $51-100 \mathrm{~cm}$ soil layer. Figure S3: Linear regressions for potentially toxic elements among three different layers in sampling region (III: $n=29)$, A: The $0-20 \mathrm{~cm}$ soil layer; B: The 21-50 cm soil layer; and C: The 51-100 cm soil layer. Table S1: The detailed information for sampling sites. Table S2: Descriptive statistical analysis of $\mathrm{Mn}$ and potentially toxic elements $(\mathrm{Zn}, \mathrm{Cu}, \mathrm{Cd}, \mathrm{Ni}, \mathrm{Co}$, and $\mathrm{Mn}$ ) in three sampling region (I: $n=29$; II: $n=17$; III: $n=29$ ), A: The $0-20 \mathrm{~cm}$ soil layer; B: The $21-50 \mathrm{~cm}$ soil layer; and C: The $51-100 \mathrm{~cm}$ soil layer.

Author Contributions: Conceptualization, L.M.; Formal analysis, Z.S. and G.S.; Funding acquisition, L.M. and J.A.; Investigation, L.M., Z.S., Y.G., K.S., G.S., and G.I.; Methodology, G.S.; Project administration, J.A.; Writing—original draft, L.M.; Writing — review and editing, J.A.

Funding: This research is funded by the West Light Foundation of Chinese Academy of Sciences (2016-QNXZ-A-4), Strategic Priority Research Program of Chinese Academy of Sciences (XDA20060303), and Tianshan Youth Program of Xinjiang Uygur Autonomous Region, China (2018Q008).

Acknowledgments: We thank three anonymous reviewers for their helpful comments and suggestions that improved the manuscript. We acknowledge the Strategic Priority Research Program of Chinese Academy of Sciences, West Light Foundation of Chinese Academy of Sciences, and Youth Innovation Promotion Association, CAS.

Conflicts of Interest: The authors declare no conflict of interest.

\section{References}

1. Hooke, R.L.; Martín-Duque, J.F.; Pedraza, J. Land transformation by humans: A review. GSA Today 2012, 22, 4-10. [CrossRef]

2. Vitousek, P.M.; Mooney, H.A.; Lubchenco, J.; Melillo, J.M. Human domination of Earth's ecosystems. Science 1997, 277, 494-499. [CrossRef]

3. Turner, B.L.; Lambin, E.F.; Reenberg, A. The emergence of land change science for global environmental change and sustainability. Proc. Natl. Acad. Sci. USA 2007, 104, 20666-20671. [CrossRef] [PubMed]

4. Abrahams, P.W. Soils: Their implications to human health. Sci. Total Environ. 2002, 291, 1-32. [CrossRef]

5. Karlen, D.L.; Andrews, S.S.; Weinhold, B.J.; Doran, J.W. Soil quality: Humankind's foundation for survival a research editorial by conservation professionals. J. Soil Water Conserv. 2003, 58, 171-179.

6. Dung, T.T.T.; Cappuyns, V.; Swennen, R.; Phung, N.K. From geochemical background determination to pollution assessment of heavy metals in sediments and soils. Rev. Environ. Sci. BioTechnol. 2013, 12, 335-353. [CrossRef]

7. Saaltink, R.; Griffioen, J.; Mol, G.; Birke, M. Geogenic and agricultural controls on the geochemical composition of European agricultural soils. J. Soils Sediments 2014, 14, 121-137. [CrossRef]

8. Di Giuseppe, D.; Bianchini, G.; Antisari, L.V.; Martucci, A.; Natali, C.; Beccaluva, L. Geochemical characterization and biomonitoring of reclaimed soils in the Po River Delta (Northern Italy): Implications for the agricultural activities. Environ. Monit. Assess. 2014, 186, 2925-2940. [CrossRef]

9. Linde, M.; Bengtsson, H.; Öborn, I. Concentrations and Pools of Heavy Metals in Urban Soils in Stockholm, Sweden. Water Air Soil Pollut. Focus 2001, 1, 83-101. [CrossRef]

10. Wuana, R.A.; Okieimen, F.E. Heavy metals in contaminated soils: A review of sources, chemistry, risks and best available strategies for remediation. ISRN Ecol. 2011, 2011, 402647. [CrossRef]

11. Meers, E.; Unamuno, V.R.; Du Laing, G.; Vangronsveld, J.; Vanbroekhoven, K.; Samson, R.; Diels, L.; Geebelen, W.; Ruttens, A.; Vandegehuchte, M.; et al. Zn in the soil solution of unpolluted and polluted soils as affected by soil characteristics. Geoderma 2006, 136, 107-119. [CrossRef]

12. Antoniadis, V.; Golia, E.E. Sorption of $\mathrm{Cu}$ and $\mathrm{Zn}$ in low organic matter-soils as influenced by soil properties and by the degree of soil weathering. Chemosphere 2015, 138, 364-369. [CrossRef] [PubMed]

13. He, Q.B.; Singh, B.R. Effect of organic matter on the distribution, extractability and uptake of cadmium in soils. J. Soil Sci. 1993, 44, 641-650. [CrossRef] 
14. Banks, M.K.; Schwab, A.P.; Henderson, C. Leaching and reduction of chromium in soil as affected by soil organic content and plants. Chemosphere 2006, 62, 255-264. [CrossRef]

15. Zhao, K.; Liu, X.; Xu, J.; Selim, H.M. Heavy metal contaminations in a soil-rice system: Identification of spatial dependence in relation to soil properties of paddy fields. J. Hazard. Mater. 2010, 181, 778-787. [CrossRef] [PubMed]

16. Chuluun, T.; Ojima, D. Land use change and carbon cycle in arid and semi-arid lands of East and Central Asia. Sci. China Ser. C Life Sci. 2002, 45, 48-54.

17. Kylander, M.E.; Klaminder, J.; Wohlfarth, B.; Löwemark, L. Geochemical responses to paleoclimatic changes in southern Sweden since the late glacial: The Hässeldala Port lake sediment record. J. Paleolimnol. 2013, 50, 57-70. [CrossRef]

18. Zhao, Z.M.; Zhao, C.Y.; Yan, Y.Y.; Li, J.Y.; Li, J.; Shi, F.Z. Interpreting the dependence of soil respiration on soil temperature and moisture in an oasis cotton field, central Asia. Agric. Ecosyst. Environ. 2013, 168, 46-52. [CrossRef]

19. Lal, R. Carbon sequestration in soils of central Asia. Land Degrad. Dev. 2004, 15, 563-572. [CrossRef]

20. Schiemann, R.; Glazirina, M.G.; Schär, C. On the relationship between the Indian summer monsoon and river flow in the Aral Sea basin. Geophys. Res. Lett. 2007, 34. [CrossRef]

21. Abdullaev, I.; Molden, D. Spatial and temporal variability of water productivity in the Syr Darya Basin, central Asia. Water Resour. Res. 2004, 40. [CrossRef]

22. Nezlin, N.P.; Kostianoy, A.G.; Lebedev, S.A. Interannual variations of the discharge of Amu Darya and Syr Darya estimated from global atmospheric precipitation. J. Mar. Syst. 2004, 47, 67-75. [CrossRef]

23. Ismaiylov, G.K.; Fedorov, V.M.; Nezhad, S.D.S. Assessment of possible anthropogenic changes in the runoff of the Syr Darya River on the basis of a mathematical model. Water Resour. 2007, 34, 359-371. [CrossRef]

24. Brun, F.; Berthier, E.; Wagnon, P.; Kääb, A.; Treichler, D. A spatially resolved estimate of High Mountain Asia glacier mass balances from 2000 to 2016. Nat. Geosci. 2017, 10, 668. [CrossRef] [PubMed]

25. Kriegel, D.; Mayer, C.; Hagg, W.; Vorogushyn, S.; Duethmann, D.; Gafurov, A.; Farinotti, D. Changes in glacierisation, climate and runoff in the second half of the 20th century in the Naryn basin, Central Asia. Glob. Planet. Chang. 2013, 110, 51-61. [CrossRef]

26. Sorg, A.; Mosello, B.; Shalpykova, G.; Allan, A.; Hill Clarvis, M.; Stoffel, M. Coping with changing water resources: The case of the Syr Darya river basin in Central Asia. Environ. Sci. Policy 2014, 43, 68-77. [CrossRef]

27. Siegfried, T.; Bernauer, T. Estimating the performance of international regulatory regimes: Methodology and empirical application to international water management in the Naryn/Syr Darya basin. Water Resour. Res. 2007, 43. [CrossRef]

28. Yao, J.Q.; Chen, Y.N. Trend analysis of temperature and precipitation in the Syr Darya Basin in Central Asia. Theor. Appl. Climatol. 2015, 120, 521-531. [CrossRef]

29. Aizen, V.B.; Aizen, E.M.; Melack, J.M.; Dozier, J. Climatic and hydrologic changes in the Tien Shan, central Asia. J. Clim. 1997, 10, 1393-1404. [CrossRef]

30. Sorg, A.; Bolch, T.; Stoffel, M.; Solomina, O.; Beniston, M. Climate change impacts on glaciers and runoff in Tien Shan (Central Asia). Nat. Clim. Chang. 2012, 2, 725. [CrossRef]

31. Siebert, S.; Henrich, V.; Frenken, K.; Burke, J. Update of the Global Map of Irrigation Areas to Version 5; Institute of Crop Science and Resource Conservation: Bonn, Germany, 2013.

32. Indoitu, R.; Kozhoridze, G.; Batyrbaeva, M.; Vitkovskaya, I.; Orlovsky, N.; Blumberg, D.; Orlovsky, L. Dust emission and environmental changes in the dried bottom of the Aral Sea. Aeolian Res. 2015, 17, 101-115. [CrossRef]

33. Ge, Y.; Abuduwaili, J.; Ma, L.; Wu, N.; Liu, D. Potential transport pathways of dust emanating from the playa of Ebinur Lake, Xinjiang, in arid northwest China. Atmos. Res. 2016, 178, 196-206. [CrossRef]

34. Abuduwaili, J.; Liu, D.W.; Wu, G.Y. Saline dust storms and their ecological impacts in arid regions. J. Arid Land 2010, 2, 144-150. [CrossRef]

35. Hartmann, J.; Moosdorf, N. The new global lithological map database GLiM: A representation of rock properties at the Earth surface. Geochem. Geophys. Geosyst. 2012, 13. [CrossRef]

36. FAO. Harmonized World Soil Database (Version 1.2); FAO: Rome, Italy; IIASA: Laxenburg, Austria, 2012.

37. Harris, I.; Jones, P.D.; Osborn, T.J.; Lister, D.H. Updated high-resolution grids of monthly climatic observations-The CRU TS3.10 Dataset. Int. J. Climatol. 2014, 34, 623-642. [CrossRef] 
38. Alvarenga, P.; Farto, M.; Mourinha, C.; Palma, P. Beneficial Use of Dewatered and Composted Sewage Sludge as Soil Amendments: Behaviour of Metals in Soils and Their Uptake by Plants. Waste Biomass Valorization 2016, 7, 1189-1201. [CrossRef]

39. Yang, X.; Liu, J.; McGrouther, K.; Huang, H.; Lu, K.; Guo, X.; He, L.; Lin, X.; Che, L.; Ye, Z.; et al. Effect of biochar on the extractability of heavy metals $(\mathrm{Cd}, \mathrm{Cu}, \mathrm{Pb}$, and $\mathrm{Zn})$ and enzyme activity in soil. Environ. Sci. Pollut. Res. 2016, 23, 974-984. [CrossRef]

40. Lee, C.S.L.; Li, X.; Shi, W.; Cheung, S.C.N.; Thornton, I. Metal contamination in urban, suburban, and country park soils of Hong Kong: A study based on GIS and multivariate statistics. Sci. Total Environ. 2006, 356, 45-61. [CrossRef]

41. Pelica, J.; Barbosa, S.; Reboredo, F.; Lidon, F.; Pessoa, F.; Calvão, T. The paradigm of high concentration of metals of natural or anthropogenic origin in soils-The case of Neves-Corvo mine area (Southern Portugal). J. Geochem. Explor. 2018, 186, 12-23. [CrossRef]

42. Tume, P.; González, E.; King, R.W.; Cuitiño, L.; Roca, N.; Bech, J. Distinguishing between natural and anthropogenic sources for potentially toxic elements in urban soils of Talcahuano, Chile. J. Soils Sediments 2018, 18, 2335-2349. [CrossRef]

43. Khudur, L.S.; Gleeson, D.B.; Ryan, M.H.; Shahsavari, E.; Haleyur, N.; Nugegoda, D.; Ball, A.S. Implications of co-contamination with aged heavy metals and total petroleum hydrocarbons on natural attenuation and ecotoxicity in Australian soils. Environ. Pollut. 2018, 243, 94-102. [CrossRef]

44. Idris, A.M. Combining multivariate analysis and geochemical approaches for assessing heavy metal level in sediments from Sudanese harbors along the Red Sea coast. Microchem. J. 2008, 90, 159-163. [CrossRef]

45. Yıldırım, G.; Tokalığlu, S.. Heavy metal speciation in various grain sizes of industrially contaminated street dust using multivariate statistical analysis. Ecotoxicol. Environ. Saf. 2016, 124, 369-376. [CrossRef] [PubMed]

46. Han, Y.; Du, P.; Cao, J.; Eric, P. Multivariate analysis of heavy metal contamination in urban dusts of Xi'an, Central China. Sci. Total Environ. 2006, 355, 176-186.

47. Huang, J.J.S.; Lin, S.C.; Löwemark, L.; Liou, S.Y.H.; Chang, Q.; Chang, T.K.; Wei, K.Y.; Croudace, I.W. Rapid assessment of heavy metal pollution using ion-exchange resin sachets and micro-XRF core-scanning. Sci. Rep. 2019, 9, 6601. [CrossRef]

48. Cao, X.; Wang, X.; Tong, W.; Gurajala, H.K.; Lu, M.; Hamid, Y.; Feng, Y.; He, Z.; Yang, X. Distribution, availability and translocation of heavy metals in soil-oilseed rape (Brassica napus L.) system related to soil properties. Environ. Pollut. 2019, 252, 733-741. [CrossRef] [PubMed]

49. Yadav, I.C.; Devi, N.L.; Singh, V.K.; Li, J.; Zhang, G. Spatial distribution, source analysis, and health risk assessment of heavy metals contamination in house dust and surface soil from four major cities of Nepal. Chemosphere 2019, 218, 1100-1113. [CrossRef] [PubMed]

50. Liu, E.; Yan, T.; Birch, G.; Zhu, Y. Pollution and health risk of potentially toxic metals in urban road dust in Nanjing, a mega-city of China. Sci. Total Environ. 2014, 476-477, 522-531. [CrossRef]

51. Taylor, S.R. Abundance of chemical elements in the continental crust: A new table. Geochim. Cosmochim. Acta 1964, 28, 1273-1285. [CrossRef]

52. Cheng, Z.; Chen, L.J.; Li, H.H.; Lin, J.Q.; Yang, Z.B.; Yang, Y.X.; Xu, X.X.; Xian, J.R.; Shao, J.R.; Zhu, X.M. Characteristics and health risk assessment of heavy metals exposure via household dust from urban area in Chengdu, China. Sci. Total Environ. 2018, 619-620, 621-629. [CrossRef]

53. Tasdemir, Y.; Kural, C. Atmospheric dry deposition fluxes of trace elements measured in Bursa, Turkey. Environ. Pollut. 2005, 138, 462-472. [CrossRef] [PubMed]

54. Liu, W.H.; Zhao, J.Z.; Ouyang, Z.Y.; Söderlund, L.; Liu, G.H. Impacts of sewage irrigation on heavy metal distribution and contamination in Beijing, China. Environ. Int. 2005, 31, 805-812. [CrossRef] [PubMed]

55. Chen, H.; Teng, Y.; Lu, S.; Wang, Y.; Wang, J. Contamination features and health risk of soil heavy metals in China. Sci. Total Environ. 2015, 512, 143-153. [CrossRef] [PubMed]

56. Wu, S.; Peng, S.; Zhang, X.; Wu, D.; Luo, W.; Zhang, T.; Zhou, S.; Yang, G.; Wan, H.; Wu, L. Levels and health risk assessments of heavy metals in urban soils in Dongguan, China. J. Geochem. Explor. 2015, 148, 71-78. [CrossRef]

57. Kamunda, C.; Mathuthu, M.; Madhuku, M. Health Risk Assessment of Heavy Metals in Soils from Witwatersrand Gold Mining Basin, South Africa. Int. J. Environ. Res. Public Health 2016, 13, 663. [CrossRef] [PubMed] 
58. Jiang, Y.; Chao, S.; Liu, J.; Yang, Y.; Chen, Y.; Zhang, A.; Cao, H. Source apportionment and health risk assessment of heavy metals in soil for a township in Jiangsu Province, China. Chemosphere 2017, 168, 1658-1668. [CrossRef] [PubMed]

59. Ferreira-Baptista, L.; De Miguel, E. Geochemistry and risk assessment of street dust in Luanda, Angola: A tropical urban environment. Atmos. Environ. 2005, 39, 4501-4512. [CrossRef]

60. Gu, Y.G.; Gao, Y.P.; Lin, Q. Contamination, bioaccessibility and human health risk of heavy metals in exposed-lawn soils from 28 urban parks in southern China's largest city, Guangzhou. Appl. Geochem. 2016, 67, 52-58. [CrossRef]

61. Qing, X.; Yutong, Z.; Shenggao, L. Assessment of heavy metal pollution and human health risk in urban soils of steel industrial city (Anshan), Liaoning, Northeast China. Ecotoxicol. Environ. Saf. 2015, 120, 377-385. [CrossRef]

62. Lu, X.; Zhang, X.; Li, L.Y.; Chen, H. Assessment of metals pollution and health risk in dust from nursery schools in Xi'an, China. Environ. Res. 2014, 128, 27-34. [CrossRef]

63. Zhang, W.; Ma, L.; Abuduwaili, J.; Ge, Y.; Issanova, G.; Saparov, G. Distribution Characteristics and Assessment of Heavy Metals in the Surface Water of the Syr Darya River, Kazakhstan. Pol. J. Environ. Stud. 2019. [CrossRef]

64. Sungur, A.; Soylak, M.; Yilmaz, E.; Yilmaz, S.; Ozcan, H. Characterization of Heavy Metal Fractions in Agricultural Soils by Sequential Extraction Procedure: The Relationship Between Soil Properties and Heavy Metal Fractions. Soil Sediment Contam. 2015, 24, 1-15. [CrossRef]

65. Ma, X.; Zuo, H.; Tian, M.; Zhang, L.; Meng, J.; Zhou, X.; Min, N.; Chang, X.; Liu, Y. Assessment of heavy metals contamination in sediments from three adjacent regions of the Yellow River using metal chemical fractions and multivariate analysis techniques. Chemosphere 2016, 144, 264-272. [CrossRef] [PubMed]

66. Marrugo-Negrete, J.; Pinedo-Hernández, J.; Díez, S. Assessment of heavy metal pollution, spatial distribution and origin in agricultural soils along the Sinú River Basin, Colombia. Environ. Res. 2017, 154, 380-388. [CrossRef] [PubMed]

67. Ross, S.M. Sources and Forms of Potentially Toxic Metals in Soil-Plant Systems. In Toxic Metals in Soil-Plant Systems; Ross, S.M., Ed.; John Wiley \& Sons Ltd.: Chichester, UK, 1994; pp. 3-25.

68. Yang, Q.; Li, Z.; Lu, X.; Duan, Q.; Huang, L.; Bi, J. A review of soil heavy metal pollution from industrial and agricultural regions in China: Pollution and risk assessment. Sci. Total Environ. 2018, 642, 690-700. [CrossRef]

69. Lazo, P.; Steinnes, E.; Qarri, F.; Allajbeu, S.; Kane, S.; Stafilov, T.; Frontasyeva, M.V.; Harmens, H. Origin and spatial distribution of metals in moss samples in Albania: A hotspot of heavy metal contamination in Europe. Chemosphere 2018, 190, 337-349. [CrossRef] [PubMed]

70. Ma, L.; Abuduwaili, J.; Li, Y.; Ge, Y. Controlling Factors and Pollution Assessment of Potentially Toxic Elements in Topsoils of the Issyk-Kul Lake Region, Central Asia. Soil Sediment Contam. 2018, 27, 147-160. [CrossRef]

71. Ma, L.; Abuduwaili, J.; Li, Y.; Liu, W. Anthropogenically disturbed potentially toxic elements in roadside topsoils of a suburban region of Bishkek, Central Asia. Soil Use Manag. 2019, 35, 283-292. [CrossRef]

72. Qiao, P.; Lei, M.; Yang, S.; Yang, J.; Guo, G.; Zhou, X. Comparing ordinary kriging and inverse distance weighting for soil as pollution in Beijing. Environ. Sci. Pollut. Res. 2018, 25, 15597-15608. [CrossRef] [PubMed]

73. Bhuiyan, M.A.H.; Parvez, L.; Islam, M.A.; Dampare, S.B.; Suzuki, S. Heavy metal pollution of coal mine-affected agricultural soils in the northern part of Bangladesh. J. Hazard. Mater. 2010, 173, 384-392. [CrossRef]

74. Wang, S.; Cai, L.M.; Wen, H.H.; Luo, J.; Wang, Q.S.; Liu, X. Spatial distribution and source apportionment of heavy metals in soil from a typical county-level city of Guangdong Province, China. Sci. Total Environ. 2019, 655, 92-101. [CrossRef] [PubMed]

75. Luo, X.S.; Xue, Y.; Wang, Y.L.; Cang, L.; Xu, B.; Ding, J. Source identification and apportionment of heavy metals in urban soil profiles. Chemosphere 2015, 127, 152-157. [CrossRef]

76. Ćujić, M.; Dragović, S.; Đorđević, M.; Dragović, R.; Gajić, B. Environmental assessment of heavy metals around the largest coal fired power plant in Serbia. Catena 2017, 148, 26-34. [CrossRef] 
77. Xu, F.; Hu, B.; Yuan, S.; Zhao, Y.; Dou, Y.; Jiang, Z.; Yin, X. Heavy metals in surface sediments of the continental shelf of the South Yellow Sea and East China Sea: Sources, distribution and contamination. Catena 2018, 160, 194-200. [CrossRef]

78. Islam, M.S.; Ahmed, M.K.; Raknuzzaman, M.; Habibullah, A.L.; Mamun, M.; Islam, M.K. Heavy metal pollution in surface water and sediment: A preliminary assessment of an urban river in a developing country. Ecol. Indic. 2015, 48, 282-291. [CrossRef]

79. Yan, G.; Mao, L.; Liu, S.; Mao, Y.; Ye, H.; Huang, T.; Li, F.; Chen, L. Enrichment and sources of trace metals in roadside soils in Shanghai, China: A case study of two urban/rural roads. Sci. Total Environ. 2018, 631, 942-950. [CrossRef]

(C) 2019 by the authors. Licensee MDPI, Basel, Switzerland. This article is an open access article distributed under the terms and conditions of the Creative Commons Attribution (CC BY) license (http://creativecommons.org/licenses/by/4.0/). 